\title{
A new species of Parasopubia (Orobanchaceae) from the southern Western Ghats, India
}

\author{
Divya Korappara VENUGOPAL ${ }^{1}$, Santhosh NAMPY2*, Ayilliath Kuttiyeri PRADEEP ${ }^{3}$, Dani FRANCIS ${ }^{4}$, Vishnu \\ MOHAN $^{5}$, Syam Radh SASI ${ }^{6}$ \\ ${ }^{1-6}$ Department of Botany, University of Calicut, Malappuram, Kerala, India.
}

*Correspondence: santhoshnampy2019@gmail.com

${ }^{1}$ http://orcid.org/0000-0003-2732-5588, ${ }^{2}$ http://orcid.org/0000-0001-5744-7522

${ }^{3} \mathrm{http}: / /$ orcid.org/0000-0003-0994-5599, ${ }^{4} \mathrm{http}: / /$ orcid.org/0000-0002-1431-2369

${ }^{5} \mathrm{http}: / /$ orcid.org/0000-0001-7702-9184, ${ }^{6} \mathrm{http}: / / o r c i d . o r g / 0000-0002-5697-6972$

\begin{abstract}
Parasopubia raghavendrae, a new species of Orobanchaceae is described from the southern Western Ghats of Kerala. It resembles $P$. delphinifolia and $P$. hofmannii var. hofmannii by its habit, shape, colour and hairiness of corolla lobes but differs by length of calyx tube, hairiness of staminal filaments and stomium, and shape and ornamentation of seeds. Parasopubia raghavendrae is hitherto known only from the type locality Mathikettan Shola National Park in Idukki district, Kerala. Detailed description of the new species along with colour photographs and comparison with its closely similar species are given. We also assessed provisionally the conservation status of the new species as Critically Endangered (CR) according to IUCN Red List Categories and Criteria.
\end{abstract}

Keywords. Critically Endangered, Idukki, Mathikettan Shola National Park, Orobanchaceae, Parasopubia raghavendrae.
Resumen. Parasopubia raghavendrae, una nueva especie de Orobanchaceae se describe para el sur del Ghats occidental de Kerala. Se asemeja a P. delphinifolia y $P$. hofmannii var. hofmannii por su hábito, forma, color e indumento de los lóbulos de la corola, y difiere de ellas por la longitud del tubo del cáliz, indumento del filamento estaminal y del estomio, y la forma y ornamentación de las semillas. Hasta ahora, $P$. raghavendrae solo se conoce para la localidad tipo del Parque Nacional de Mathikettan Shola, en el distrito de Idukki, Kerala. Se proporciona la descripción detallada de la nueva especie junto con fotografías en color y una comparativa con las especies más similares. Así mismo, se evalúa provisionalmente el estado de conservación de la nueva especie con la categoría en Peligro Crítico (CR) de acuerdo a los Criterios de la Lista Roja de la UICN.

Palabras clave. En Peligro Crítico, Idukki, Parque Nacional de Mathikettan Shola, Orobanchaceae, Parasopubia raghavendrae.

How to cite this article: Venugopal D.K., Nampy S., Pradeep A.K., Francis D., Mohan V., Sasi S.R. 2021. Anew species of Parasopubia (Orobanchaceae) from the southern Western Ghats, India. Anales del Jardin Botánico de Madrid 78: e106. https://doi.org/10.3989/ajbm.2585

Title in Spanish: Una nueva especie de Parasopubia (Orobanchaceae) del sur de las Ghats occidentales, India.

Associate Editor: Ana Ortega. Received: 22 January 2021; accepted: 24 February 2021; published online: 15 June 2021

\section{INTRODUCTION}

Orobanchaceae, commonly called 'broomrapes', is the largest parasitic angiosperm family with morphologically diverse herbaceous plants (Young \& al. 1999). Most of the species are facultative or obligate root parasites which may be photosynthetic (hemiparasites) or totally depend on host plants (holoparasites). Parasopubia H.-P.Hofm. $\&$ Eb.Fisch., a genus of Orobanchaceae recently segregated from Sopubia Ham. ex D.Don (Hofmann \& Fischer 2004), is characterized by slightly zygomorphic flowers, corolla tube much longer than lobes and acuminate reduced thecae. The genus comprises four taxa, including the new species here described, distributed in South East Asia. Parasopubia bonatii H.-P.Hofm. \& Eb.Fisch. is distributed in Cambodia, Laos, Vietnam, Thailand and China
(Bonati 1927) while P. delphinifolia (L.) H.-P.Hofm. \& Eb.Fisch., P. hofmannii Pradeep \& Pramod var. hofmannii and $P$. hofmannii var. albiflora Pradeep \& Pramod are found in India (Pradeep \& Pramod 2013) (Fig. 1). Members of this genus are usually seen in grasslands, wet rocks, cultivated lands, marshy areas, lateritic hillocks and moist deciduous forests.

During our field work in Idukki district, Kerala, an interesting species of Parasopubia was collected from Mathikettan Shola National Park (MSNP). After careful comparison of Parasopubia specimens and consulting relevant literature, the authors found that it was quite distinct from other taxa in the genus and hence is described here as a new species. 


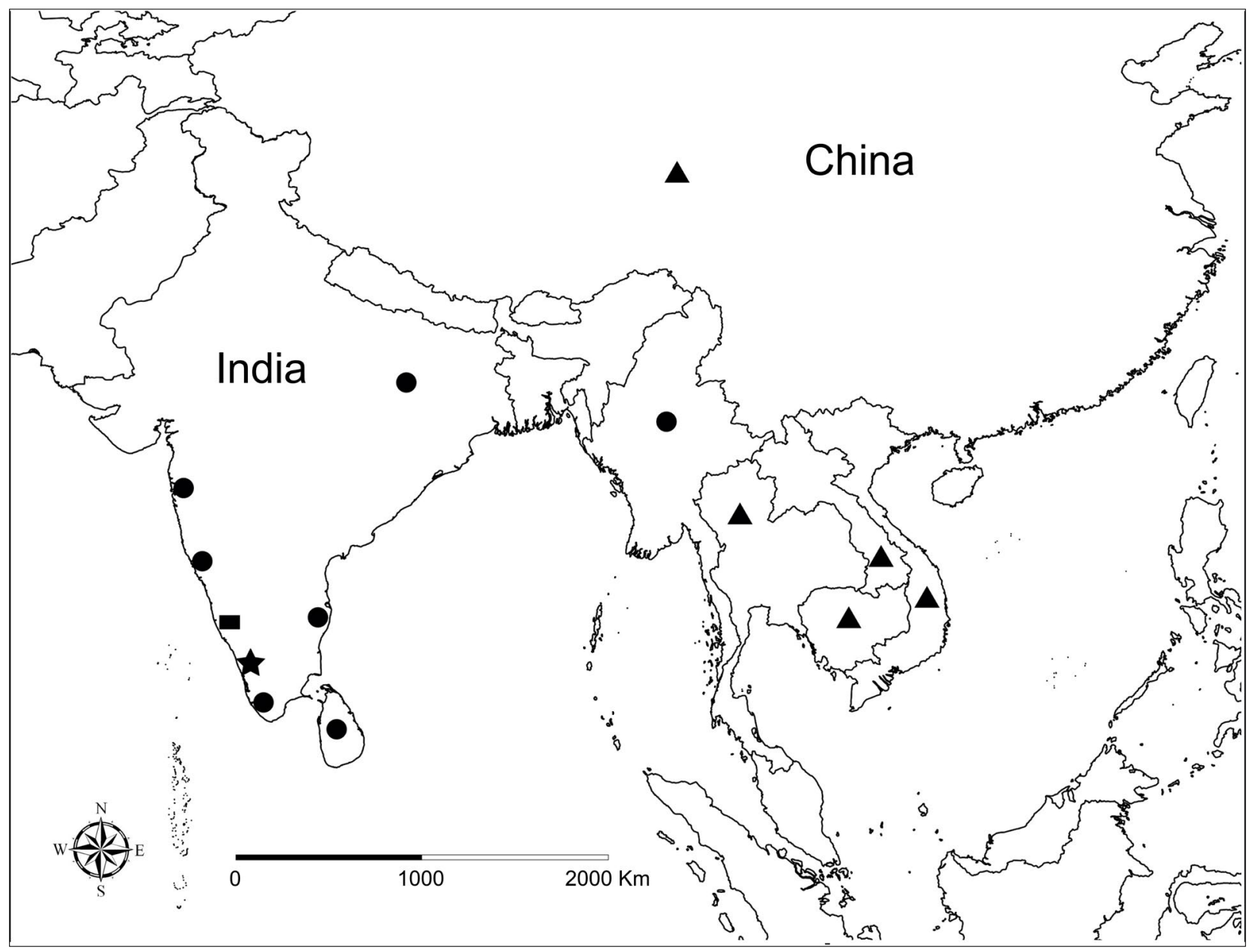

Fig. 1. Map showing the approximate location of the known herbarium records of Parasopubia species: P. delphinifolia (circle), P. bonatii (triangle), P. hofmannii (square), P. raghavendrae (star). Base map modified from version available at https://d-maps.com.

\section{MATERIALS AND METHODS}

Fresh specimens were collected from Mathikettan Shola National Park of Idukki district. Protologues and relevant literature (Bonati 1927; Hofmann \& Fischer 2004; Pradeep $\&$ Pramod 2013) were examined for confirming the identity of the specimens and detailed descriptions were made. The following virtual herbaria were also searched for confirming the identity of the specimens: $\mathrm{K}, \mathrm{M}$ and $\mathrm{S}$ (acronyms according to Thiers 2021, continuously updated). Herbarium sheets were prepared as per Bridson and Forman (1991). Conservation assessment was done using IUCN standards and petition committee criteria (IUCN 2019). The photographs of floral parts were taken with a Stemi 508 Stereomicroscope attached to an Axiocam 105 colour Camera (Zeiss, Germany). The ultra-morphological analysis of seeds was done using DM6 B Phase Contrast Microscope fitted with a DFC450 Camera (Leica, Switzerland) and Gemini 300 Scanning Electron Microscope (Zeiss, Germany).

\section{RESULTS AND DISCUSSION}

\section{Taxonomic treatment}

Parasopubia raghavendrae Divya \& Nampy, sp. nov. Type: India, Kerala: Idukki district, Mathikettan Shola National Park (MSNP), Sivanpara, \pm 1610 m, 11 Dec. 2016, D.K. Venugopal \& S. Nampy 151405 (holotype: CALI!; isotypes: CALI!, CAL!). Fig. 2.

Diagnosis. - It is similar to Parasopubia delphinifolia and P. hofmannii var. hofmannii but can be easily distinguished by the calyx with tube exceeding lobes (4-4.5 mm against 3.5-3.8 mm long), the glandular hairy staminal filaments and stomium, the oblong capsules and seeds in contrast with the calyx tube less long than calyx lobes $(2-2.5 \mathrm{~mm}$ against $4 \mathrm{~mm}$ long in P. hofmannii var. hofmannii; $4 \mathrm{~mm}$ against $7 \mathrm{~mm}$ long in $P$. delphinifolia), and glabrous staminal filaments and stomium. The capsules are elliptic and the seeds obovate in $P$. delphinifolia while obovoid and obovate, respectively in $P$. hofmannii var. hofmannii. The 


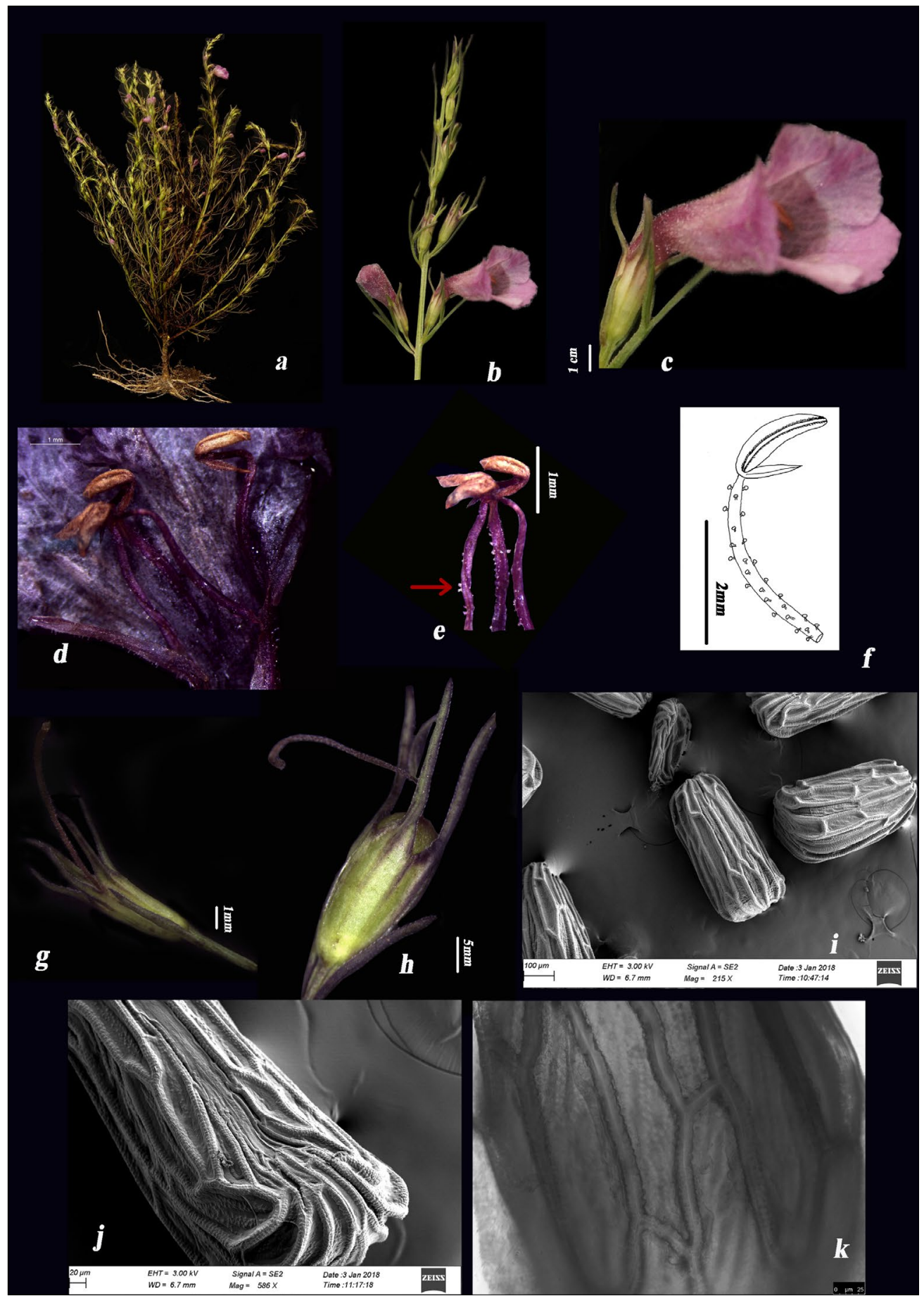

Fig. 2. Parasopubia raghavendrae Divya \& Nampy sp. nov.: a, habit; b, flowering twig with leaves; c, flower; d, didynamous stamens; e, glandular hairs on filaments; $\mathbf{f}$, illustration of filament with glandular hairs; $\mathbf{g}$, calyx tube and lobes; $\mathbf{h}$, capsule; $\mathbf{i}-\mathbf{j}$, SEM images of seeds; $\mathbf{k}$, phase contrast image of seed [from: MSNP 151405; photos: Divya K. Venugopal; scale: $\mathrm{c}=1 \mathrm{~cm} ; \mathrm{d}=1 \mathrm{~mm} ; \mathrm{e}=1 \mathrm{~mm} ; \mathrm{f}=2 \mathrm{~mm} ; \mathrm{g}=1 \mathrm{~mm} ; \mathrm{h}=5 \mathrm{~mm} ; \mathrm{i}=100 \mu \mathrm{m} ; \mathrm{j}=20$ $\mu \mathrm{m}, \mathrm{k}=25 \mu \mathrm{m}]$.

testa is uniformly ribbed and parallely reticulate with wide testa cells in $P$. raghavendrae while non-uniformly ribbed and obliquely reticulate in $P$. hofmannii var. hofmannii and $P$. delphinifolia. However, the testa cells are narrow in the former and wide in the latter.
Annual herbs up to $50 \mathrm{~cm}$ tall. Stems terete at base, 4-angular above, densely branched (branches 6-30), green. Leaves opposite, 2-5 cm long, sessile; lower leaves 5-7 segmented; segments linear-lanceolate to filiform; upper leaves entire; midrib prominent abaxially, strigose on 
margins, green. Flowers axillary, solitary, bisexual, zygomorphic, $1-1.5 \times 0.5-1 \mathrm{~cm}$. Pedicels $1-1.5 \mathrm{~cm}$ long, tomentose, green; bracteoles 2, linear, 2-2.3 $\times 0.5-1 \mathrm{~mm}$, glabrous, green. Calyx 5-lobed, persistent in fruit; tube 4-4.5 mm long, longer than lobes, glabrous; lobes linear, $3.5-3.8 \times 1-1.1 \mathrm{~mm}$, acute at apex, glabrous, green. Corolla campanulate, puberulent on outer surface, glabrous on inner surface, pink; tube $6.8-7 \times 1-1.5 \mathrm{~mm}$; lobes nearly sub-rotund, 3-3.2 × 4-4.1 m m. Stamens 4, unequal, inserted on corolla tube; filaments deep pink, 2 longer (6 $\mathrm{mm}$ long), 2 shorter (5 $\mathrm{mm}$ long), glandular hairy; anthers 2 , pendent, thecae pale brown, one fertile and one sterile, unequal; fertile thecae $2 \times 1 \mathrm{~mm}$; sterile thecae $1 \times 1 \mathrm{~mm}$; stomium hairy, opening whole length. Ovary superior, 1 $\times 1 \mathrm{~mm}$, ellipsoid, 2-celled, glabrous, green; ovules many in each cell; style slender, $8-8.2 \times 1-1.1 \mathrm{~mm}$, puberulent distally, pale pink; stigma globose, glabrous. Capsules oblong, erect, 5-5.3 mm long, glabrous; 3/4 portion enclosed in calyx tube; fruiting calyx lobes erect. Seeds numerous, oblong, $0.57 \mathrm{~mm}$ long, brown; testa uniformly ribbed and parallely reticulate with wide testa cells.

Distribution and habitat.-The new species is hitherto known only from the type locality. It grows in wet humus-rich rock crevices at an elevation of c. $1610 \mathrm{~m}$ along with Murdannia satheeshiana Joby, Nisha \& Unni, Cyanotis sp. (both Commelinaceae), Eriocaulon sp. (Eriocaulaceae), Polycarpaea corymbosa (L.) Lam. (Caryophyllaceae), etc.

Phenology. - Flowering and fruiting from early December to late January.
Etymology.-The new species is named in honour of Dr. R. Raghavendra Rao, for his contributions in Indian botany.

Provisional conservation status. - The new species is currently known only from the type locality in the Mathikettan Shola National Park. Two populations with approximately 15 mature individuals were observed in two successive years (2017-2019) and the populations were separated by a distance of around $300 \mathrm{~m}$. There is no possible threat as the area falls under a National Park. On the basis of available data, this species is categorized provisionally as Critically Endangered (CR) (by considering area of occupancy $<10$ $\mathrm{km}^{2}\left[\mathrm{~B}_{2}\right]$; number of mature individuals in each population $\leq 50\left[\mathrm{C}_{2} \mathrm{a}\right]$; very small or restricted population with number of mature individuals $<50$ [D]) as per IUCN Red List Categories and Criteria (IUCN, 2019).

Notes. - It is worth mentioning that Parasopubia raghavendrae shares the habit and hairiness of corolla lobes with other taxa of Parasopubia in India. Parasopubia raghavendrae is peculiar by its hairy staminal filaments and stomium, uniformly ribbed testa and parallely reticulate wide testa cells. It grows in wet, humus rich non-lateritic rocks, while $P$. hofmannii var. hofmannii grows in lateritic rocks and $P$. delphinifolia in almost all habitats (in grasslands, cultivated lands, marshes, lateritic rocks and non-lateritic rocks, etc.). The flowering period of the three taxa are: $P$. delphinifolia from August to February, P. hofmannii var. hofmannii from July to September while $P$. raghavendrae from December to January. A comparison of diagnostic characters between $P$. delphinifolia, $P$. hofmanni var. hofmannii and P. raghavendrae is given in Table 1.

Table 1. Diagnostic morphological characters of Parasopubia raghavendrae Divya \& Nampy sp. nov. and comparison with morphologically similar species.

\begin{tabular}{|c|c|c|c|}
\hline Character & P. delphinifolia & P. hofmannii var. hofmannii & P. raghavendrae \\
\hline Calyx tube length & $4 \mathrm{~mm}$; shorter than calyx lobes & 2-2.5 mm; shorter than calyx lobes & 4-4.5 mm; longer than calyx lobes \\
\hline Calyx lobes length, shape & $7 \mathrm{~mm}$, lanceolate & $4 \mathrm{~mm}$, linear & 3.5-3.8 mm, linear \\
\hline $\begin{array}{l}\text { Staminal filaments indu- } \\
\text { ment and length }\end{array}$ & $\begin{array}{l}\text { Glabrous } \\
\text { Longer filaments } 5 \mathrm{~mm} \\
\text { Shorter filaments } 4 \mathrm{~mm}\end{array}$ & $\begin{array}{l}\text { Glabrous } \\
\text { Longer filaments } 5 \mathrm{~mm} \\
\text { Shorter filaments } 3 \mathrm{~mm}\end{array}$ & $\begin{array}{l}\text { Glandular hairy } \\
\text { Longer filaments } 6 \mathrm{~mm} \\
\text { Shorter filaments } 5 \mathrm{~mm}\end{array}$ \\
\hline Fertile and sterile thecae & Equal, $2 \mathrm{~mm}$ long & Equal, $1.5 \mathrm{~mm}$ long & $\begin{array}{l}\text { Unequal } \\
\text { Fertile thecae }>2 \mathrm{~mm} \text { long } \\
\text { Sterile thecae } 1 \mathrm{~mm} \text { long }\end{array}$ \\
\hline Stomium & $\begin{array}{l}\text { Glabrous } \\
\text { Opening from apex }\end{array}$ & $\begin{array}{l}\text { Glabrous } \\
\text { Opening from base }\end{array}$ & $\begin{array}{l}\text { Hairy } \\
\text { Opening whole length }\end{array}$ \\
\hline Fruiting calyx lobes & Erect & Divergent from capsule & Erect \\
\hline Capsules & $\begin{array}{l}\text { Elliptic } \\
\text { Slightly pubescent } \\
\text { Enclosed in calyx tube }\end{array}$ & $\begin{array}{l}\text { Obovoid } \\
\text { Glabrous } \\
1 / 2 \text { of the capsule enclosed in calyx } \\
\text { tube }\end{array}$ & $\begin{array}{l}\text { Oblong } \\
\text { Glabrous } \\
3 / 4 \text { of the capsule enclosed in calyx tube }\end{array}$ \\
\hline Seeds & $\begin{array}{l}\text { Obovate } \\
\text { Non-uniformly ribbed with wide } \\
\text { oblique reticulate cells }\end{array}$ & $\begin{array}{l}\text { Obovate } \\
\text { Non-uniformly ribbed with narrow } \\
\text { oblique reticulate cells }\end{array}$ & $\begin{array}{l}\text { Oblong } \\
\text { Uniformly ribbed with wide parallel } \\
\text { reticulate cells }\end{array}$ \\
\hline
\end{tabular}


Key to the species of genus Parasopubia including the new species

1. Plants stout; calyx lobes broadly triangular, without linear extension P. bonatii

- Plants slender; calyx lobes linear or lanceolate, with linear extension ...2

2. Fruiting calyx lobes erect 3

- Fruiting calyx lobes divergent

3 Calyx with tube shorter than lobes; calyx lobes lanceolate; stomium opening from apex; capsules elliptic, slightly pubescent P. delphinifolia

- Calyx with tube longer than lobes; calyx lobes linear; stomium opening whole length; capsules oblong, glabrous $P$. raghavendrae

4. Corolla pale pink; plant parts often purplish; testa cells narrow P. hofmannii var. hofmannii

- Corolla white; plant parts without purplish tinge; testa cells wide P. hofmannii var. albiflora

Additional specimens examined.-Parasopubia delphinifolia. INDIA. Kerala: Malappuram district, Kozhippara, 21 Oct. 2009, A.K. Pradeep 90072 (CALI 152574); C U Campus, 22 Nov. 1989, Ushakumari V.N. 4878 (CALI 152663); ibid., 02 Sep. 1990, Solly George 3238 (CALI 152665). Tamil Nadu: Coimbatore district, Mount Stouert, 27 Oct. 1961, J. Joseph 13377 (MH 00125774, MH 00125773); Dharmapuri district, Dhoddikere, 22 Dec. 1990, T. Ravishankar 95524 (MH 00125763, MH 00125762). s.d., s.coll., s.n. (M 0188641 digital image); s.loc., 1 Jan. 1777, Johann G. Konig s.n. (S 09-26708 digital image); s.loc., 1831, N. Wallich 3890 (K 000999981 digital image)._-Parasopubia hofmanni var. hofmannii. INDIA. Kerala: Kannur district, Madayippara, 27 Nov. 2011, Pramod CU 151405 (holotype CALI); ibid., 11 Sep. 2009, Pramod CU 123592 (CALI); ibid., 01 Aug. 2010, Pramod CU 126510 (CALI); ibid., 20 Aug. 2010, Pramod CU 126555 (CALI).

\section{ACKNOWLEDGEMENTS}

Authors are grateful to the head of the Department of Botany, University of Calicut for the facilities; curators and staffs of CALI and MH for permitting to study the specimens; Chief Wildlife Warden (Kerala) and Officials of MSNP for granting permission to explore the MSNP; Central Sophisticated Instrumentation Facility (CSIF), University of Calicut for SEM facility. The study is funded by Kerala State Council for Science, Technology and Environment, Thiruvananthapuram (126/2016// KSCSTE dated 26 May 2016).

\section{REFERENCES}

Bonati G. 1927. Scrophulariacées. In: Lecomte H. \& Humbert H. (eds.), Flore Générale de I'Indo-Chine 4: 341-461. Messon et Cie Éditeurs, Paris.

Bridson D.M. \& Forman L. 1991. The Herbarium Handbook. Royal Botanic Gardens, Kew.

Hofmann H.-P. \& Fischer E. 2004. Generic delimitation of Sopubia Buch.-Ham. (Scrophulariaceae), revision of Petitmenginia bonati and description of the new Asian genus Parasopubia. Botanische Jahrbücher für Systematik, Pflanzengeschichte und Pflanzengeographie 125: 341-375.

IUCN 2019. The IUCN Red List of Threatened Species. Version 20192. IUCN Species Survival Commission. Gland, Switzerland.

Pradeep A.K \& Pramod C. 2013. Parasopubia hofmannii Pradeep \& Pramod and Parasopubia hofmannii var. albiflora Pradeep \& Pramod (Orobanchaceae), two new taxa from India. Candollea 68: 115-122.

Thiers B.M. 2021 [continuously updated]. Index Herbariorum: A global directory of public herbaria and associated staff. New York Botanical Garden's Virtual Herbarium. Website: http://sweetgum.nybg.org/ih/ [accessed: 18 Feb. 2021].

Young N.D., Steiner K.E. \& Depamphilis C.W. 1999. The evolution of parasitism in Scrophulariaceae/Orobanchaceae: plastid gene sequences refute an evolutionary transition series. Annals of the Missouri Botanical Garden 86: 876-893. 